\title{
Characterization of the immunopathogenic responses to ovalbumin peptide 323-339 in experimental immune-mediated blepharoconjunctivitis in Lewis rats
}

\author{
A. Fukushima, K. Nishino, O. Yoshida and H. Ueno
}

Laboratory of Immunology, Department of Ophthalmology, Kochi Medical School, Kohasu, Oko-cho, Nankoku 783-8505, Japan

\begin{abstract}
Purpose. We recently reported the essential role of cellular immunity on the induction of experimental immune-mediated blepharoconjunctivitis (EC, formerly EAC) by using ovalbumin (OVA) as a model antigen in Lewis rats. The purpose of this study was to investigate the possible induction of EC by immunization with an OVA peptide (OVA 323-339).
\end{abstract}

Methods. Lewis rats were immunized with various doses of OVA or OVA 323-339 in complete Freund's adjuvant. Three weeks later they were challenged with OVA or OVA 323-339 by eye drops; $24 \mathrm{~h}$ after challenge, eyes including lids, lymph nodes and blood were harvested after clinical evaluation. An OVA 323-339-specific cell line (S816) was established by periodical stimulation with this peptide. Pathogenicity of S816 was tested by adoptive transfer of S816 into syngeneic recipient rats after challenge with OVA or OVA 323-339.

Results. All rats immunized with OVA 323-339 developed EC after challenge with OVA or OVA 323-339. Rats immunized with OVA 323-339 at doses as low as $0.01 \mu \mathrm{g}$ had severe clinical scores. OVA-primed rats also developed EC after challenge with OVA 323-339. OVA-primed lymph node cells responded to OVA but not to OVA 323-339. OVA 323-339-primed lymph node cells responded to OVA 323-339 but not to OVA and produced IFN- $\gamma$ by stimulation with either OVA or OVA 323-339 (three- to fourfold more than with OVA-primed lymph node cells). Recipient rats of S816 developed severe EC after challenge with either OVA or OVA 323-339.

Conclusion. OVA 323-339 was identified as a potent pathogenic peptide in EC. Curr. Eye Res. 17:763-769, 1998.

Key words: experimental immune-mediated blepharo conjunctivitis; ovalbumin; peptide; Lewis rat; cellular immunity

Correspondence: Atsuki Fukushima, Laboratory of Immunology, Department of Ophthalmology, Kochi Medical School, Kohasu, Oko-cho, Nankoku 7838505 , Japan

\section{Introduction}

Allergic conjunctivitis is a group of diseases caused by hypersensitive reactions in the conjunctiva to innocuous antigens. ${ }^{1}$ In general, type 1 immediate immune response is thought to be mainly involved in the etiology of this disease. ${ }^{2}$ Vernal keratoconjunctivitis (VKC) is a type of allergic conjunctivitis whose most typical clinical characteristic is giant papillae in the palpebral conjunctiva. ${ }^{3}$ In addition to type 1 immune response, involvement of type 4 delayed-type immune response was demonstrated in the development of VKC. ${ }^{4,5}$

As we previously reported, active immunization with ovalbumin (OVA) in complete Freund's adjuvant (CFA) induced experimental immune-mediated blepharoconjunctivitis (EC, formerly EAC) in Lewis rats. ${ }^{6}$ Nitzan et al. ${ }^{7}$ reported the successful induction of experimental conjunctivitis in guinea pigs by immunization with OVA in CFA. In addition, passive immunization by adoptive transfer of OVA-primed lymph node cells caused syngeneic recipient rats to develop EC. ${ }^{6}$ It was concluded that cellular immunity is involved in both the induction and effector phases of EC development. The importance of cellular immunity on the development of EC is in accord with the reports on upregulated cellular infiltration of conjunctiva in VKC patients. ${ }^{4,5}$

For the induction of cellular immunity, especially $\mathrm{T}$ cellmediated immune responses, antigen-presenting cells must present peptide fragments of the protein to T cells. ${ }^{8,9}$ The peptide-major histocompatibility complex (MHC) molecules further bind to $\mathrm{T}$ cell receptor (TcR), and the formation of these trimolecular complexes is essential for activating $\mathrm{T}$ cells to induce their effector functions. Therefore, studies on $\mathrm{T}$ cellmediated immune responses have come to focus on determining antigenic peptides, $\mathrm{T}$ cell binding epitopes, and $\mathrm{MHC}$ binding agretopes. ${ }^{10}$

In experimental autoimmune disease models such as experimental autoimmune encephalomyelitis (EAE) and experimental autoimmune uveitis (EAU), fragments of autoantigens critical for the development of diseases were identified and the

Received on October 21, 1998; revised and accepted on April 14, 1998

(C) 1998 Oxford University Press 
specificity of these fragments for agretopes or epitopes were analyzed. ${ }^{1-13}$ In general, these peptides can induce diseases efficiently by immunization at much lower doses than required for native proteins.

Previous reports concerning OVA peptides indicated that OVA 323-339 has a high affinity to MHC class II molecules in Lewis rats and several strains of mice. ${ }^{14,15}$ Renz et al. ${ }^{16}$ reported that sensitization with OVA 323-339 induced systemic allergen-specific immunoglobulin E (IgE) responses and upregulation of airway responsiveness in BALB/c mice. They also compared allergic airway hyperresponsiveness induced by OVA and OVA 323-339. ${ }^{17}$ This information led us to investigate the ability of OVA 323-339 to induce EC in Lewis rats.

We investigated the disease-inducing capability of OVA 323339 by using this peptide as a challenge antigen as well as an immunizing antigen. In addition, we demonstrated that adoptive transfer of an OVA 323-339-specific CD4+ T cell line could induce EC much more efficiently than could transfer of lymph node cells primed with OVA or OVA 323-339.

\section{Materials and methods}

\section{Rats}

Six- to eight-week-old male Lewis rats were purchased from a commercial source (Seac Yoshitomi, Fukuoka, Japan) and maintained in a pathogen-free animal facility at Kochi-Medical School. All animal procedures conformed to institutional guidelines and the ARVO Resolution on Use of Animals in Research.

\section{Antigen and peptide}

OVA (grade 5, Sigma Immunochemicals, St. Louis, MO) or OVA peptide 323-339 (OVA 323-339; ISQAVHAAHAE INEAGR) was used for either immunizing or challenge antigens. OVA 323-339 was synthesized by solid-phase chemistry using $t$-butyloxycarbonyl derivatives of the amino acids and purified by HPLC to at least $95 \%$ purity (Sawady Technology, Tokyo, Japan).

\section{Antibodies}

Anti-CD4 and anti-CD8 (Pharmingen, San Diego, CA) were labeled with fluorescein isothiocyanate. Anti-CD3 and anti-CD25 (Pharmingen, San Diego, CA); anti-IA (OX-3) and anti-CD45RA (OX-33) (Serotec, Oxford, England); and anti-CD11a (LFA-1 $\alpha$ ) and anti-CD54 (ICAM-1) (Caltag Laboratories, Burlingame, CA) were labeled with biotin.

\section{Sensitization, challenge, and evaluation of EC}

Rats were injected subcutaneously with $100 \mu \mathrm{g}$ of either OVA or OVA 323-339 in CFA (Yatoron, Tokyo, Japan). In another set of experiments, different doses $(0.01,0.1,1,10$, or $100 \mu \mathrm{g})$ of OVA 323-339 were used. Three weeks later the rats were challenged with either OVA or OVA 323-339 by eye drops as reported. ${ }^{6}$ Rats were clinically evaluated $24 \mathrm{~h}$ after challenge and their eyes, lymph nodes, and blood were harvested for rou- tine histology, proliferation assay, and antibody titer by ELISA, respectively. For clinical grading, discharge and lid swelling were assessed and each finding was scored as 1 point. The clinical grading system is summarized as follows: 0: no signs in both eyes; 1: discharge or lid swelling only in one eye; 2: discharge in both eyes, lid swelling in both eyes, or discharge in one eye and lid swelling in one eye; 3 : discharge in both eyes and lid swelling in one eye or lid swelling in both eyes and discharge in one eye; and 4: discharge in both eyes and lid swelling in both eyes. The number of infiltrated cells in the palpebral conjunctiva was counted and presented as cells $/ \mathrm{mm}^{2}$. We previously described the correlation between clinical grading and cell count. ${ }^{6}$

\section{Assessment for cellular immune responses of primed lymph node cells}

Lymph nodes were combined per group and experiments were repeated three times. Lymphocyte proliferation assays were set up in quadruplicate in 96-well flat-bottom plates. Lymph node cells $\left(3 \times 10^{5}\right.$ cells/well) were cultured in a final volume of 0.2 ml RPMI 1640 medium supplemented with 5\% fetal calf serum (FCS; ICN Biomedical Japan Co., Tokyo, Japan), 2 mercaptoethanol (2-ME, $\left.5 \times 10^{-5} \mathrm{M}\right)$, L-glutamine $(2 \mathrm{mM})$, penicillin $(100 \mathrm{U} / \mathrm{ml})$, and streptomycin $(100 \mu \mathrm{g} / \mathrm{ml})$. Cells were stimulated with either OVA or OVA 323-339 at final concentrations of $0.1,1,10$, or $100 \mu \mathrm{g} / \mathrm{ml}$. After incubation for 72 $\mathrm{h}$ at $37^{\circ} \mathrm{C}$ in a humidified atmosphere with $5 \% \mathrm{CO}_{2}$, cultures were pulsed for $16 \mathrm{~h}$ with $0.5 \mu \mathrm{Ci} /$ well of ${ }^{3} \mathrm{H}$-thymidine (Japan Atomic Energy Research Institute, Tokai, Japan). Cultures were then harvested and the radioactivity was measured by standard techniques. Data were expressed as stimulation indices.

\section{Assessment of humoral immune responses}

Serum was collected from rats via cardiac puncture when they were euthanized. Serum antibody levels against OVA were measured by direct ELISA. OVA (500 ng/well) was adsorbed to 96 -well plates for $2 \mathrm{~h}$ at $37^{\circ} \mathrm{C}$. The plates were washed with PBS-Tween, and serially diluted serum samples were added to the wells. Bound antibody was detected by peroxidase-conjugated anti-IgG or IgE (Nordic Immunological Laboratories, Tilburg, The Netherlands). The plates were developed by using 3,3',5,5'-tetramethylbenzidine base (TMB-ELISA, GIBCO BRL, Gaithersburg, MD), and the optical density for each well was read at $610 \mathrm{~nm}$.

\section{Cytokine ELISA using culture supernatant}

Lymph nodes from rats primed with either OVA or OVA 323339 were combined for culture. Cells were prepared as described above. For 3 days, $100 \times 10^{6}$ cells were cultured in $25 \mathrm{~cm}^{2}$ flasks (Nunc, Roskilde, Denmark) with OVA at $50 \mu \mathrm{g} /$ $\mathrm{ml}$ or OVA $323-339$ at $10 \mu \mathrm{g} / \mathrm{ml}$ in a final volume of $10 \mathrm{ml}$ RPMI 1640 medium containing $5 \times 10^{-5}$ M 2-ME and $10 \%$ FCS. Culture supernatants were harvested and assayed by commercial cytokine ELISA (BioSource International, Camarillo, CA) for interferon-gamma (IFN- $\gamma$ ) concentrations, with strict adherence to the recommended method. 


\section{Establishment of OVA 323-339 specific cell line (S816)}

To establish a cell line specific to OVA 323-339, we followed the method of $\mathrm{Hu}$ et al. ${ }^{18}$ In brief, lymph node cells primed with OVA 323-339 were cultured with OVA 323-339 at $10 \mu \mathrm{g} /$ $\mathrm{ml}$ for 3 days as described above. They were expanded with recombinant human interleukin-2 (rhIL-2, Takeda, Osaka, Japan) for 3 days. After the expansion period, the cells were resuspended with irradiated (30 Gy) syngeneic thymocytes in the presence of OVA 323-339 at $10 \mu \mathrm{g} / \mathrm{ml}$. Three days later, live lymphocytes were separated by gradient centrifugation (Lymphocyte Separation Medium, Organon Teknika Corporation, West Chester, PA) and expanded with rhIL-2. This stimulation-expansion cycle was repeated for 3-5 times. For disease induction, cells were used just after stimulation, whereas cells after expansion were used for the proliferation assay.

\section{Flow cytometric analysis}

S816 cells were incubated for $45 \mathrm{~min}$ on ice with the primary antibodies listed above $\left(0.08-2 \mathrm{mg}\right.$ for $2 \times 10^{6}$ cells $)$ and washed repeatedly with cold 5\% FCS-PBS. Streptavidin-PE (Pharmingen, San Diego, CA) was added to cells stained with biotin-conjugated antibodies for $10 \mathrm{~min}$ and washed again. The cells were then analyzed by using FACScan (Becton Dickinson, Mountain View, CA).

\section{Proliferative responses of S816}

Rested S816 cells were used for this assay, and cultures were set up as described above. S816 cells $\left(3 \times 10^{4}\right)$ were cultured with $6 \times 10^{5}$ irradiated (30 Gy) syngeneic thymocytes as antigen-presenting cells together with antigens. ${ }^{18}$ The cultures were incubated for $72 \mathrm{~h}$, with a pulse of ${ }^{3} \mathrm{H}$-thymidine given for the last $16 \mathrm{~h}$. Radioactivity was measured as above.

\section{Induction of $\mathrm{EC}$ by adoptive transfer of $\mathrm{S816}$}

Activated S816 cells $\left(1.5 \times 10^{6}\right)$ were injected intravenously into syngeneic recipient rats. Four days after transfer, recipients were challenged with either OVA or OVA 323-339 by eye drops and $24 \mathrm{~h}$ after challenge were clinically evaluated and euthanized for histological study.

\section{Statistical analysis}

Statistical comparison of the number of infiltrated cells in each group was performed by using Student's $t$-test.

\section{Results}

\section{Induction of EC by peptide OVA 323-339}

To evaluate the disease-inducing capacity of OVA 323-339, we compared it with whole OVA for its capacity as both the immunizing and challenge antigen. As seen in Table 1, the peptide resembled whole OVA in the two antigenic activities; both clinical grading and the number of infiltrating cells were similar when the disease was induced by the protein or the peptide. Further, similar levels of disease severity were also observed in
Table 1. Induction of EC: Comparison of OVA and OVA 323-339

\begin{tabular}{lcc}
\hline $\begin{array}{l}\text { Immunizing Ag, } \\
\text { Challenge Ag a }\end{array}$ & $\begin{array}{c}\text { Clinical } \\
\text { grading } \\
\text { (mean } \pm \text { SD) }\end{array}$ & $\begin{array}{c}\text { Infiltrated } \\
\text { cell number } \\
\text { (mean } \pm \text { SD) }\end{array}$ \\
\hline OVA, OVA & $2.00 \pm 0.00$ & $127 \pm 32$ \\
OVA 323-339, OVA & $2.00 \pm 0.00$ & $130 \pm 50$ \\
OVA, OVA 323-339 & $1.83 \pm 0.41$ & $130 \pm 34$ \\
OVA 323-339, & $1.83 \pm 0.41$ & $123 \pm 45$ \\
\hline
\end{tabular}

a $100 \mathrm{mg}$ of antigen with CFA was administered subcutaneously; antigen challenge was by eye drops. ${ }^{\mathrm{b}}$ No statistically significant differences were detected among these four groups; $\mathrm{n}=6$ rats per group.

rats in which the peptide served as the immunizing or challenge antigen, with OVA being used as the other antigen. The major histological feature of EC induced by OVA 323-339 was mononuclear cellular infiltration, which is quite similar to that seen in EC induced by OVA. Statistical analysis of the disease parameters in the four groups showed $\mathrm{p}$-values of $>0.63$.

\section{Induction of EC at various doses of OVA 323-339}

To further determine disease-inducing capacity of OVA 323 339, we tested the peptide at various doses. As shown in Table 2, peptide OVA 323-339 was found to cause severe EC in rats immunized with doses as low as $0.01 \mu \mathrm{g}$. There were no statistically significant differences on infiltrated cell number among these five groups $(\mathrm{p}>0.19)$.

\section{Stimulation of cellular immune response by peptide OVA 323-339}

Rats immunized with different doses of OVA 323-339 were also tested for their cellular immune responses by the lymphocyte proliferation assay. As shown in Table 3, rats immunized with the peptide developed vigorous proliferative responses.

Table 2. Induction of EC by OVA 323-339: Comparison of immunized dose

\begin{tabular}{lcc}
$\begin{array}{l}\text { Immunizing } \\
\begin{array}{l}\text { dose } \\
(\mu g)\end{array}\end{array}$ & $\begin{array}{c}\text { Clinical grading } \\
(\text { mean } \pm \mathrm{SD})\end{array}$ & $\begin{array}{c}\text { Infiltrated cell number } \\
(\text { mean } \pm \mathrm{SD})\end{array}$ \\
\hline 100 & $2.75 \pm 0.50$ & $235 \pm 70$ \\
10 & $2.75 \pm 0.50$ & $255 \pm 38$ \\
1 & $3.00 \pm 0.00$ & $246 \pm 71$ \\
0.1 & $2.50 \pm 0.58$ & $244 \pm 54$ \\
0.01 & $3.25 \pm 0.95$ & $250 \pm 48$ \\
\hline
\end{tabular}

andicated dose of antigen was immunized with CFA subcutaneously; OVA was used as challenge in these rats. ${ }^{b}$ No statistically significant differences were detected among these five groups; $n=4$ per group. 
The magnitude of response declined gradually when lower doses of OVA 323-339 were used for immunization.

\section{Cross reactivity between OVA 323-339 and the whole OVA protein}

To examine the cross-reactivity between peptide OVA 323-339 and the whole OVA protein, we tested lymphocytes from rats sensitized with either one of these antigens for their proliferative responses against the peptide or whole OVA. As seen in Figure 1A, rats immunized with OVA reacted well against the protein, but showed only marginal responses against the peptide. Similarly, rats sensitized against OVA 323-339 responded well to the peptide, but not to the whole OVA protein (Figure 1B). These results were obtained in two more separate experiments.

\section{Humoral immune responses of rats primed with OVA or OVA 323-339}

Rats immunized with OVA or OVA 323-339 were also tested for their humoral response against the whole protein. OVAprimed serum contained a high titer of $\operatorname{IgG}$ against OVA. OVA 323-339-primed serum contained low levels of OVA-specific IgG compared with OVA-primed serum (Fig. 1C). Concentrations of OVA-specific IgE were low, if present, after immunization with OVA or OVA 323-339 (data not shown).

\section{IFN- $\gamma$ production of lymph node cells primed with OVA or OVA 323-339 in vitro}

Lymph node cells primed with OVA or OVA 323-339 were also examined for their capacity to produce IFN- $\gamma$ when stimulated in culture with the protein or the peptide. There was no difference between OVA 323-339- and OVA-stimulated production of IFN- $\gamma$ by OVA-primed lymph node cells (Fig. 2). IFN- $\gamma$ in OVA-primed cells stimulated with OVA was approximately one-fourth of that in OVA 323-339-primed cells stimulated with OVA. OVA 323-339-primed cells stimulated with OVA produced more IFN- $\gamma$ than did the same cells stimulated with OVA 323-339, without exhibiting significant cellular proliferation (Fig. 1B).

Table 3. Stimulation of cellular immune responses by OVA 323-339

\begin{tabular}{lc}
$\begin{array}{l}\text { Immunizing dose } \\
(\mu \mathrm{g})\end{array}$ & $\begin{array}{r}\text { Proliferative responses } \\
\text { @ }\end{array}$ \\
\hline 100 & OVA 323-339 \\
10 & 19.5 \\
1 & 12.4 \\
0.1 & 27.1 \\
0.01 & 6.0 \\
\hline
\end{tabular}

Indicated dose of antigen was immunized with CFA subcutaneously; OVA was used as challenge in these rats. ${ }^{\text {b}}$ The antigen concentration in vitro was $100 \mathrm{mg} / \mathrm{ml}$ and data were recorded as S.I. values. Background c.p.m. of each group was as follows: $2472 \pm 33(100 \mu \mathrm{g}), 531 \pm 26(10 \mu \mathrm{g}), 1441 \pm 77$ (1 $\mu \mathrm{g}), 1426 \pm 96(0.1 \mu \mathrm{g}), 617 \pm 56(0.01 \mu \mathrm{g})$.
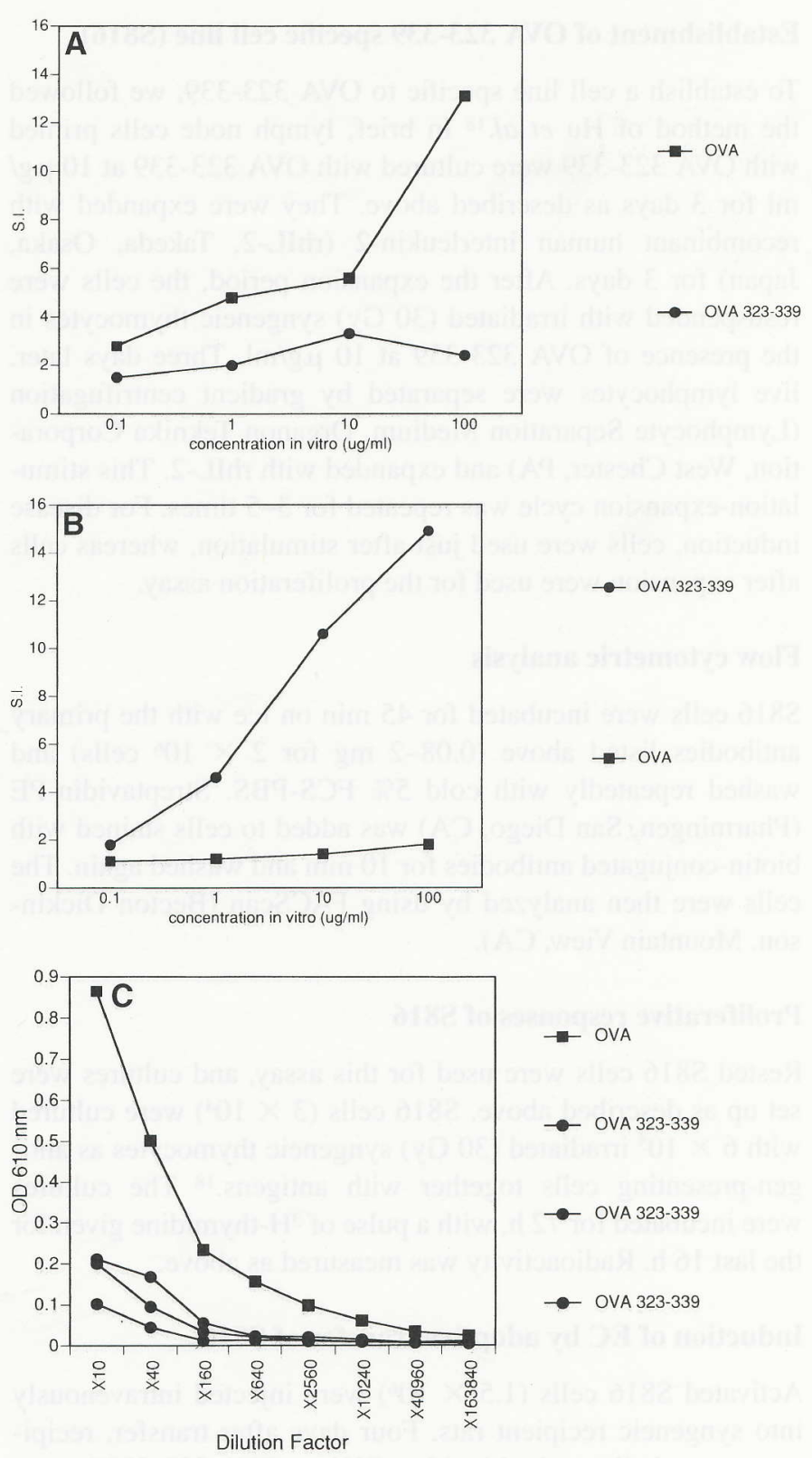

Figure 1. Proliferative responses of OVA-(A) and OVA 323-339primed (B) lymph node cells. Cells were harvested and tested for proliferation. Data are means of values from two rats. Squares: OVA protein used as the antigen; circles: OVA 323-339 used as the antigen. The combined mean c.p.m. \pm SE values for the unstimulated control cultures were $263 \pm 21$ for (A) and $284 \pm 12$ for (B). Measurement of OVA-specific IgG by ELISA in serum from Lewis rats immunized with either OVA or OVA 323-339 (C). Serum was collected when the rats were euthanized and assayed.

\section{Phenotypical and immunological properties of a cell line specific to OVA 323-339}

FACScan analysis revealed that the cell surface marker for cell line S816 was CD3+, CD4+, CD8-, and LFA-1+ (Table 4). Some cells expressed activation markers such as CD25 and OX-3 (Table 4). S816 responded vigorously to OVA 323-339 at concentrations as low as $0.1 \mu \mathrm{g} / \mathrm{ml}$ (Fig. 3). In addition, S816 
immunized antigen challenged antigen

OVA 323-339 - OVA 323-339

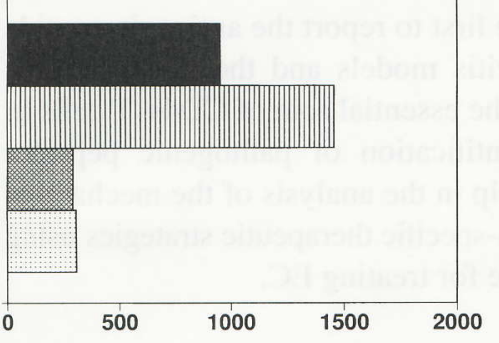

OVA 323-339 - OVA

OVA - OVA 323-339

OVA - OVA

$\mathrm{pg} / \mathrm{ml}$

Figure 2. IFN- $y$ production of culture supernatant of OVA- or OVA 323-339-primed lymph node cells. Primed lymph node cells were cultured with either OVA or OVA 323-339 and supernatants were collected for IFN- $\gamma$ ELISA.

reacted to OVA protein (Fig. 3), although OVA 323-339primed lymph node cells did not respond to OVA protein.

\section{EC induced by adoptive transfer of S816}

Adoptive transfer of $1.5 \times 10^{6}$ cells of S816 induced severe clinical changes with massive cellular infiltration (Table 5). Histological features of EC induced by adoptive transfer of S816 were similar to those induced by active immunization of OVA or OVA 323-339. Most of infiltrated cells were mononuclear leukocytes. There was no statistically significant difference in the number of infiltrated cells between challenges with OVA or OVA 323-339 ( $\mathrm{p}>0.75)$.

\section{Discussion}

In recent years, the development of technology for investigating synthetic peptides has revealed details of the mechanism of TcR-MHC interaction. CD4+ T cells generally recognize about 13-mer peptides on MHC class II molecules of antigenpresenting cells, and this recognition is crucial for $\mathrm{T}$ cell activation. ${ }^{19}$ Pathogenic and immunogenic peptides associated with infectious 20 and autoimmune diseases ${ }^{11-13}$ have been identified and used for treatment of experimental disease models as well as induction of these models.

OVA is known to be a food allergen ${ }^{21}$ and is often used as a model allergen in experimental allergic diseases. ${ }^{16,17}$ As we previously reported, ${ }^{6} \mathrm{EC}$ was induced in Lewis rats by immunization with OVA in adjuvants. The amino acid sequence of OVA was defined and several portions of OVA were identified

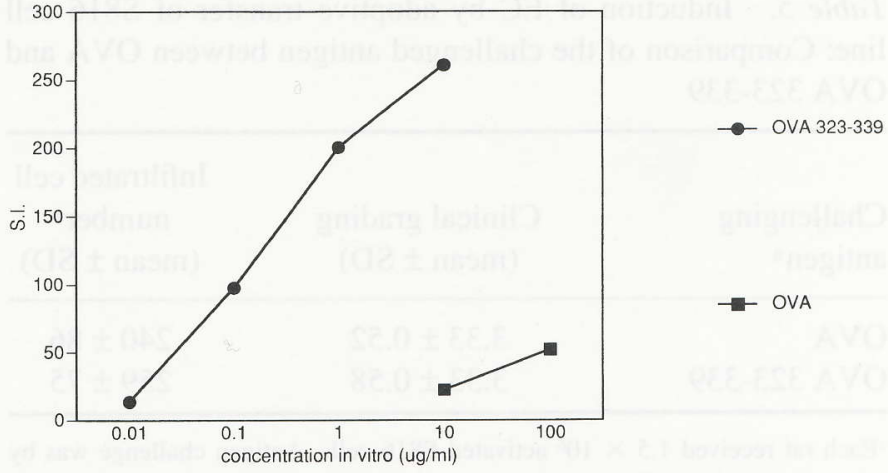

Figure 3. Proliferative responses of S816 cell line. Rested S816 cells were cultured as described. Squares: OVA protein was used as the antigen; circles: OVA 323-339 used as the antigen. The combined mean c.p.m. \pm SE value for the unstimulated control cultures was $44 \pm 5$.

to have a high affinity for MHC class II molecules. Joosten et al. ${ }^{14}$ reported that OVA $323-339$ has a high binding affinity for RT1 molecules in Lewis rats, which prompted us to investigate the involvement of OVA 323-339 in Lewis rats with EC.

One important difference between autoimmune response and allergic response is the character of target antigens. Target antigen for autoimmunity is endogenous, while that for allergy is exogenous. In addition, the nature of immune response is also different. Type 1 and type 4 immune reactions are involved in ocular allergy, 6,7,22 whereas the major effector mechanism of autoimmune diseases such as EAU is type 4 immune reaction. ${ }^{12,23}$ Despite these differences, $\mathrm{T}$ cell-mediated immune responses are apparently involved in both EC and EAU.6,23 EAU was reported to be induced efficiently by uveitogenic peptides, although some of these peptides could not induce significant cellular proliferation. ${ }^{24}$ In agreement with this notion, OVA 323-339 induced quite weak proliferation of OVAprimed lymph node cells (Fig. 1A), whereas OVA 323-339primed lymph node cells proliferated vigorously against this peptide (Fig. 1B). These data, along with the data in Table 1, show that OVA 323-339 is not highly immunodominant but is immunogenic, with pathogenicity after topical challenge with OVA or OVA 323-339, indicating the dissociation of pathogenicity and immunodominance for OVA 323-339 in EC, as demonstrated in EAU.

Cellular immunity against OVA is important for the induction of EC. ${ }^{6}$ To assess cellular immunity, cellular proliferative responses in vitro for antigens are commonly used. Measurement of cytokine production is also an important method for assessing the quality of CD4+ $\mathrm{T}$ cell-mediated immunity.

Table 4. Cell surface molecules expressed in S816 cells

\begin{tabular}{lrrrrrrrr}
\hline & CD3 & CD4 & CD8 & OX-3 & OX-33 & CD25 & LFA-1 & ICAM-1 \\
\hline \% positive & 98.9 & 99.0 & 0.5 & 22.6 & 0.1 & 98.2 & 99.2 & 41.7 \\
MFI $^{\text {a }}$ & 104.8 & 477.8 & 30.5 & 10.3 & 2.2 & 387.7 & 103.6 \\
\hline
\end{tabular}

a\%positive: percentage of cells expressing the molecule in all cells. ${ }^{b}$ MFI: mean fluorescence intensity. 
Table 5. Induction of EC by adoptive transfer of S816 cell line: Comparison of the challenged antigen between OVA and OVA 323-339

\begin{tabular}{lcc}
$\begin{array}{l}\text { Challenging } \\
\text { antigen }\end{array}$ & $\begin{array}{c}\text { Clinical grading } \\
(\text { mean } \pm \text { SD })\end{array}$ & $\begin{array}{c}\text { Infiltrated cell } \\
\text { number }^{\mathrm{b}} \\
(\text { mean } \pm \text { SD })\end{array}$ \\
\hline OVA & $3.33 \pm 0.52$ & $240 \pm 86$ \\
OVA 323-339 & $3.33 \pm 0.58$ & $259 \pm 75$ \\
\hline
\end{tabular}

aEach rat received $1.5 \times 10^{6}$ activated 5816 cells. Antigen challenge was by

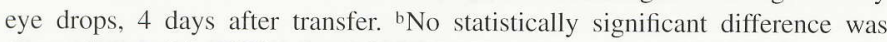
detected; $\mathrm{n}=6$ for OVA, $\mathrm{n}=3$ for OVA 323-339.

Therefore, we used ELISA to measure IFN- $\gamma$ production in the culture supernatant of stimulated lymph node cells. Although antigen concentration in vitro was not the same for OVA and OVA 323-339, OVA 323-339-primed lymph node cells tend to produce more IFN- $\gamma$ than do OVA-primed lymph node cells (Fig. 2). Furthermore, the amount of IFN- $\gamma$ produced by stimulation with the antigen, which was not the immunizing antigen, is at least the same as that produced by stimulation with immunizing antigen in lymph node cells primed with OVA or OVA 323-339, which produced IFN- $\gamma$ with minimal proliferation against OVA 323-339 or OVA (Fig. 1A, 1B). These data might contribute to the dissociation of pathogenicity and immunodominance of OVA 323-339 on the development of EC.

Successful induction of EC by immunization with $0.01 \mu \mathrm{g}$ of OVA 323-339 further supported that OVA 323-339 is a highly pathogenic peptide (Table 2 ). Although cellular immune responses of rats immunized with more than $1 \mu \mathrm{g}$ of OVA 323339 and evaluated by proliferation assay were superior to those of rats immunized with less than $0.1 \mu \mathrm{g}$ (Table 3 ), there were no apparent differences in clinical grading scores as well as no statistically significant differences $(0.19<\mathrm{P}<0.97)$ among rats immunized with different doses. These data also suggest that OVA 323-339 is highly pathogenic and that other factors, such as IFN- $\gamma$, in addition to cellular proliferation are important for the induction of EC.

Although we reported that adoptive transfer of OVA-primed lymph node cells induced EC in Lewis rats, ${ }^{6}$ whether cellular immunity alone is involved in the development of EC remained unclear, because transferred cells were a mixture of $\mathrm{T}$ cells and $\mathrm{B}$ cells. Therefore, transfer of purified $\mathrm{T}$ cells is necessary to clarify the involvement of $\mathrm{T}$ cells on the induction of EC. We established S816, which is a CD4+ T cell line (Table 4) and proliferates vigorously by stimulation with OVA or OVA 323 339 (Fig. 3). Rats that received S816 developed severe EC with massive cellular infiltration (Table 5). Even though only 1.5 $10^{6} \mathrm{~S} 816$ cells were injected, the disease grade was as severe as that for recipients of $5010^{6}$ OVA-primed lymph node cells (data not shown). These data indicate that CD4-positive $\mathrm{T}$ cells are the main effector regarding the development of EC; OVA 323 339-specific T cells alone can induce severe EC, probably because of their high affinity to OVA fragments on the cells of conjunctiva after challenge with OVA.
In summary, OVA 323-339 is defined as a target of OVA protein for the induction of EC in Lewis rats. To the best of our knowledge, our data are the first to report the antigenic peptide in experimental conjunctivitis models and the data recorded here clearly demonstrated the essential role of CD4+ T cells in the induction of EC. Identification of pathogenic peptides shown in this study may help in the analysis of the mechanism of EC. Furthermore, antigen-specific therapeutic strategies using this peptide may be possible for treating EC.

\section{Acknowledgment}

We would like to thank Ms. Natsuko Naruoka for her technical help in preparing the histological slides.

\section{References}

1. Donshik PC. Allergic conjunctivitis. Int Ophthalmol Clin. 1988;28:294-302

2. Doherty MJ, Easty DL. Inflammatory and immunological cell profiles in a rat model of conjunctival immediate hypersensitivity. Clin Exp Allergy. 1989;19:449-455.

3. Colby K, Dohlman C. Vernal keratoconjunctivitis. Int Ophthalmol Clin. 1996;36:15-20.

4. Metz DP, Bacon AS, Holgate S, Lightman SL. Phenotypic characterization of $\mathrm{T}$ cells infiltrating the conjunctiva in chronic allergic eye disease. J Allergy Clin Immunol. 1996;98:686-696.

5. Abu el-Asrar AM, Van den Oord JJ, Geboes K, Missotten L, Emarah MH, Desmet V. Immunopathological study of vernal keratoconjunctivitis. Graefe's Arch Clin Exp Ophthalmol. 1989;227:374-379.

6. Fukushima A, Yoshida H, Iwamoto H, Yoshida O, Ueno H. The role of cellular immunity both in the induction and effector phases of experimental allergic blepharoconjunctivitis (EAC) in rats. Exp Eye Res. 1997;65:631-637.

7. Nitzan Y, Boldur I, Afgin Y, Barishak YR, Malik Z, Sompolinsky D. The dynamics of inflammation of the anterior eye in a novel experimental model for hypersensitivity. Cytobios. 1996;88:105-117.

8. Guillet JG, Lai MZ, Briner TJ, Smith JA, Gefter ML. Interaction of peptide antigens and class II major histocompatibility complex antigens. Nature. 1986;324:260262.

9. Buus S, Sette A, Colon AM, Miles C, Grey HM. The relation between major histocompatibility complex (MHC) restriction and the capacity of Ia to bind immunogenic peptides. Science. 1987;235:1353-1358.

10. Falk K, Rotzschke O, Stevanovic S, Jung G, Rammensee HG. Allele-specific motifs revealed by sequencing of selfpeptides eluted from MHC molecules. Nature. 1991;351: 290-296.

11. Ota K, Matsui M, Milford EL, Mackin GA, Weiner HL, Hafler DA. T-cell recognition of an immunodominant myelin basic protein epitope in multiple sclerosis. Nature. 1990;346:183-187.

12. Martin R, McFarland HF, McFarlin DE. Immunological 
aspects of demyelinating disease. Annu Rev Immunol. 1992; 10:153-187.

13. Greer JM, Sobel RA, Sette A, Southwood S, Lees MB, Kuchroo VK. Immunogenic and encephalitogenic epitope clusters of myelin proteolipid protein. J Immunol. 1996; 156:371-379.

14. Joosten I, Wauben MH, Holewijn MC, et al. Direct binding of autoimmune disease related $\mathrm{T}$ cell epitopes to purified Lewis rat MHC class II molecules. Int Immunol. 1994;6:751-759.

15. Buus S, Colon S, Smith C, Freed JH, Miles C, Grey HM. Interaction between a "processed" ovalbumin peptide and Ia molecules. Proc Natl Acad Sci USA. 1986;83:39683971 .

16. Renz H, Smith HR, Henon JE, Ray BS, Irvin CG, Gelfand EW. Aerosolized antigen exposure without adjuvant causes increased $\mathrm{IgE}$ production and increased airway responsiveness in the mouse. J Allergy Clin Immunol. 1992;89:11271138 .

17. Renz H, Bradley K, Larsen GL, McCall C, Gelfand EW. Comparison of the allergenicity of ovalbumin and ovalbumin peptide 323-339. J Immunol. 1993;151:7206-7213.

18. Hu LH, Redmond TM, Sanui H, et al. Rat T-cell lines specific to a nonimmunodominant determinant of a retinal protein (IRBP) produce uveoretinitis and pinealitis. Cell Immunol. 1989;122:251-261.

19. Lanzavecchia A, Reid PA, Watts C. Irreversible association of peptides with class II MHC molecules in living cells. Nature. 1992;357:249-252.

20. Kilgus J, Jardetzky T, Gorga JC, Trzeciak A, Gillessen D, Sinigaglia F. Analysis of the permissive association of a malaria T cell epitope with DR molecules. I Immunol. 1991;146:307-315.

21. Langeland T. A clinical and immunological study of allergy to hen's egg white III: Allergens in hen's egg white studied by crossed radio-immunoelectrophoresis (CRIE). Allergy. 1982;37:521-530.

22. Calonge M, Pasor JC, Herreras JM, Gonzalez JL. Pharmacological modulation of vascular permeability in ocular allergy in the rat. Invest Ophthalmol Vis Sci. 1990;31:176180.

23. Mochizuki M, Kuwabara T, McAllister C, Nussenblatt RB, Gery I. Adoptive transfer of experimental autoimmune uveoretinitis in rats: immunopathogenic mechanisms and histologic features. Invest Ophthalmol Vis Sci. 1985;26:1-9.

24. Kotake S, Wiggert B, Zhang XY, Redmond TM, Chader GJ, Gery I. Stimulation in vitro of lymphocytes for induction of uveoretinitis without any significant proliferation. $J$ Immunol. 1990;145:534-539. 